\title{
Methylation of DNA repair genes and the efficacy of DNA targeted anticancer treatment
}

\author{
Joris R. Julsing and Godefridus J. Peters* \\ *Correspondence: gj.peters@vumc.nl

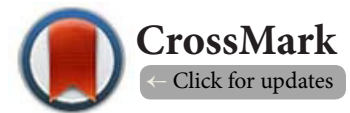

Department of Medical Oncology, VU University Medical Center, De Boelelaan 1117, 1081HV Amsterdam, Netherlands.

\begin{abstract}
Cancer is considered both a genetic and epigenetic disease. The best studied epigenetic mechanism in carcinogenesis is DNA methylation, a mechanism which inactivates tumor suppressor genes by methylating their promoters. A subclass of tumor suppressor genes that are often methylated in the process of carcinogenesis are the DNA repair genes. Accumulation of DNA damage is associated with cancer and thus inactivation of DNA repair genes promotes cancer formation. Methylation of DNA repair genes seems to be unique compared to the methylation of other tumor suppressor genes in that it not only promotes tumorigenesis, but at the same time influences the sensitivity of tumors to chemotherapies that are based on agents that damage DNA to kill cancer cells. This literature study summarizes the current knowledge regarding epigenetic inactivation of DNA repair genes and the subsequent progress that has been made coping with the acquired chemotherapy resistances.
\end{abstract}

Keywords: DNA repair, methylation, cancer, MGMT, BRCA 1, MLH 1

\section{Introduction}

Over the last decade, research on epigenetic events has increased as they play an important role in many cellular processes, including tumorigenesis. These epigenetic events refer to processes that functionally modify the genome without changing the actual nucleotide sequence, such as chromatin remodeling, histone modification, non-coding RNA, DNA acetylation and DNA methylation. DNA methylation can be considered one of the best studied epigenetic events, playing an essential role in (long-term) silencing of genes [1]. One of the reasons epigenetics has gained a lot of interest in cancer research in particular, is that these epigenetic modifications are not considered irreversible [2] and as such malignant cells could potentially be reverted back to normal healthy cells. DNA methylation not only plays a role in tumorigenesis, but also in the efficacy of anticancer drugs. This review focuses on the role of DNA methylation in the activity of DNA repair enzymes, which normally repair DNA damage caused by DNA directed anticancer agents.

\section{Review}

\section{DNA methylation in cancer}

The ability to silence genes explains the crucial role that DNA methylation has in X-chromosome inactivation [3], genomic imprinting [4], regulating gene expression as well as suppressing transposons and repetitive elements (i.e., LINE) [5]. Methylation of DNA occurs by the covalent addition of a methyl $(-\mathrm{CH} 3)$ group to a cytosine of a cytosine-phosphate-guanine $(\mathrm{CpG})$ dinucleotide. Clusters of these $\mathrm{CpG}$ dinucleotides are located in promoter regions of genes and are called $\mathrm{CpG}$ islands. The exact requirement for a DNA region to be defined as a CpG island is a length of at least $500 \mathrm{bp}$ of which $\geq 55 \%$ consists of $\mathrm{GC}$ and a ratio of observed and expected CpG $>0.65$ [6]. DNA methylation of these $\mathrm{CpG}$ islands in promoter regions silences the genes to which these particular promoter regions belong by either recruiting additional silencing associated proteins and/or lowering the accessibility of the DNA for transcription factors (TFs) [7] (Figure 1).

DNA methylation is carried out by DNA methylation transferases (DNMTs). There are 5 DNMT isoforms: DNMT1, DNMT2, DNMT3a, DNMT3b and DNMT3L; but of which only DNMT1, DNMT3a and DNMT3b actually methylate DNA. DNMT3a and DNMT3b establish de novo DNA methylation patterns, important during embryogenesis [8]. Functionally, DNMT1 differs in that its role is to maintain the established DNA methylation pattern through cell division and thus DNA replication [9]. This is done by recognition of hemi-methylated DNA by UHRF1 and directing DNMT1 towards methylating the corresponding cytosine in the newly synthesized DNA strand [10]. 
Julsing et al. Oncology Discovery 2014,

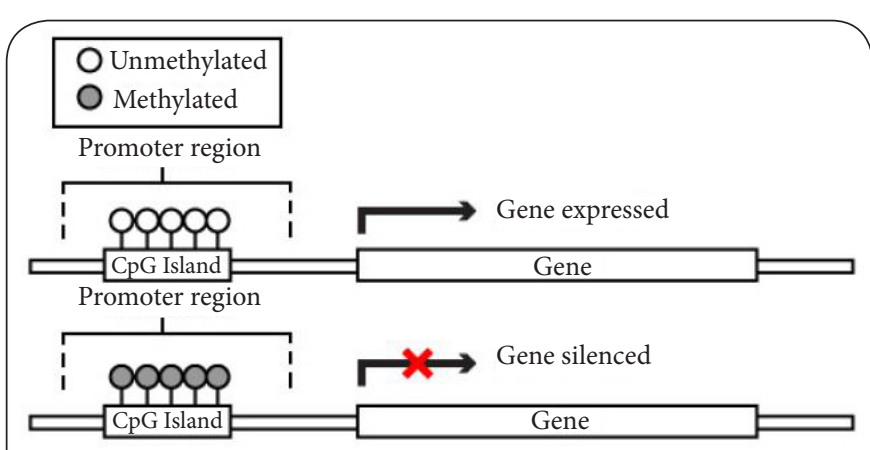

Figure 1. Simplified representation of DNA methylation. Methylation of $\mathrm{CpG}$ islands in the promoter region of a gene represses the expression of that gene, effectively 'silencing' it (modified illustration of [42]).

For a cell to develop and function normally, proper DNA methylation is critical. Therefore, any aberrations in this event can lead to diseases, including cancer. Indeed, DNA of cancer cells has a different methylation pattern than that of normal cells. In general, a global hypomethylation of DNA can be observed in cancer cells. Although rather uncommon, this can lead to activation of previously silenced oncogenes, but also contributes to genomic instability and mutagenesis by reactivation of transposable elements which then can integrate at random sites. However, local hypermethylation also takes place in the transformation into a cancer cell, namely the meth-ylation promoter regions of so called tumor suppressor genes (TSG) [11]. These are genes that play a role in the suppression of tumorigenesis in normal cells.

The genes that are hypermethylated in malignant cells often have various but also important cellular functions. For example, genes that are related to cell cycle regulation such as $\mathrm{P} 16^{\mathrm{INK} 4 \mathrm{~A}}$ and $\mathrm{P} 15^{\mathrm{INK} 4 \mathrm{~B}}$ are silenced in many cancers due to DNA methylation enabling uninhibited proliferation (e.g., [12]). Other genes often hypermethylated, and thus silenced, in cancer can be involved in: cell adhesion, such as E-cadherin and $\mathrm{H}$-cadherin, enabling invasion and/or metastasis of the tumor (e.g., [13]); apoptosis, such as DAPK1, enabling resistance to cell death (e.g., [14]); and finally genes associated with DNA repair processes are also often hypermethylated in tumors, thus suggesting that epigenetic events may promote classical genetic alterations such as mutations.

\section{DNA repair pathways and their genes}

As described above, genes involved in the repair of damaged DNA are an important class of tumor suppressor genes. The pathways in which their products act on DNA damage are part of what is considered the DNA damage response (DDR). This DDR generally protects cells against genomic instability, which is considered a characteristic of tumorigenesis [15]. As such, silencing of these genes via hypermethylation is a common occurrence in cancers. For this reason it is important to realize that the efficacy of therapies based on damaging
DNA to successfully kill cancer cells, such as radiotherapy and certain chemotherapies is largely dependent on inhibition of these DNA repair pathways [16]. There are multiple different DNA repair pathways available and the involvement of a specific pathway will depend on the type of DNA lesion that needs to be repaired.

\section{Base excision repair}

Damaged bases are excised and replaced by enzymes belonging to the base excision repair (BER) pathway. These lesions generally arise due to oxidative damage caused by reactive oxygen species (ROS). If damaged bases are ignored there is an increased chance in mispairing of the bases, potentially causing mutations. The most frequent oxidations of bases are 8-oxoguanine (8-oxoG) and 5-hydroxycytosine, which mispair with adenine and thymine respectively $[17,18]$. However, BER is also able to repair alkylated bases, namely 3-methyladenine and 7-methylguanine. The first step of BER is the removal of the damaged bases by glycosylases, resulting in apurinic or apyrimidinic (AP) sites, after which endonucleases create a single strand break (SSB). This will then be processed by DNA polymerases during either short-patch (single nucleotide replacement) or long-patch BER (2-10 nucleotides replacement). Pol $\beta$ is the main DNA polymerase that catalyzes short-patch BER, with pol $\lambda$ being able to take over in its absence [19], while DNA synthesis during long-patch BER is mediated by pol $\delta$ and pol $\varepsilon$. Pol $\delta$ and $\varepsilon$ perform displacing synthesis, generating a "displaced" DNA flap which is removed by FEN-1. The seam between new DNA and the already existing DNA strand is sealed by DNA ligase III and the XRCC1 protein in short-patch $B E R$, while this is catalyzed by DNA ligase I in long-patch BER (Figure 2A).

\section{Nucleotide excision repair}

While the BER pathway can repair specific non-bulky lesions, the nucleotide excision repair (NER) pathway can remove bulky DNA adducts such as thymine dimers, often induced by UV radiation [20]. These adducts are recognized by several proteins such as DDB, XPA and the XPC-Rad23B complex. After damage recognition, the DNA helix is unwound by Transcription factor II H (TFIIH) and subsequently two incisions are made, one at each of $3^{\prime}$ and $5^{\prime}$ end of the site. The $3^{\prime}$ end incision is made by the XPG protein, while the $5^{\prime}$ end incision is performed by the heterodimeric XPF-ERCC1 protein [21]. This leads to the removal of 25-30 nucleotides. The created gap is then filled with newly synthesized DNA by DNA polymerases $\delta$ and $\varepsilon$ after which the nicks are ligated by either DNA ligase I or DNA ligase III-XRCC1 (Figure 2B).

\section{Mismatch repair}

Mismatch repair (MMR) of DNA is specifically aimed at, as the name implies, the repair of mismatched base pairs caused by either erroneous base insertions, deletions or mis-incorporations during DNA replication. The mismatch is 


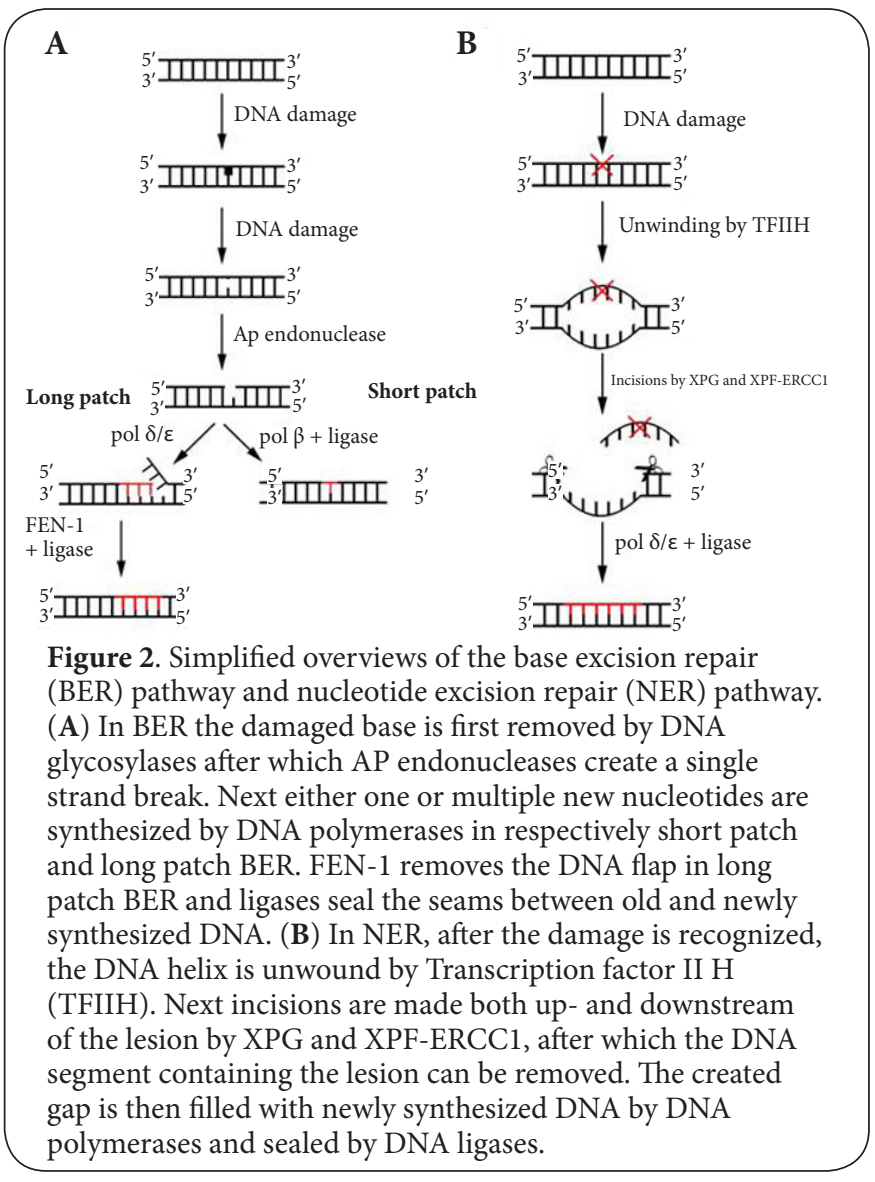

recognized by heterodimeric proteins $\mathrm{MSH} 2-\mathrm{MSH} 6$ and $\mathrm{MSH} 2-$ MSH3. Next a nick is created in the strand near the mismatch lesion by the heterodimeric protein and subsequently a segment of single strand DNA containing the mismatch is excised by exonuclease 1 (EXO1). The resulting single strand gap is then repaired by DNA polymerase $\delta$ and finally sealed by DNA ligase [22] (Figure 3A).

\section{Direct repair}

Direct reversal can be considered the simplest form of DNA repair. It is considered direct in that it does not involve breaking the phosphodiester backbone of DNA, removing nucleotides and replacing them with newly synthesized DNA. DNA damage in the form of methylation of guanine at the $\mathrm{O}^{6}$-position can be removed by the $\mathrm{O}^{6}$-methylguanine DNA methyltransferase (MGMT) protein [23]. MGMT also has the ability to remove other alkylations of the $\mathrm{O}^{6}$-position of guanine [23] (Figure 3B). Unrepaired $\mathrm{O}^{6}$-methylguanine lesions can lead to mutagenesis as distorted pairing of guanine with cytosine or thymidine leads to $\mathrm{G}: \mathrm{C}$ to $\mathrm{A}: \mathrm{T}$ transitions on replication [24], triggering cytotoxicity and apoptosis if left unrepaired [25]. The removal of the methyl group from guanine by MGMT as the transferase and acceptor is a stoichiometric reaction. This means a single MGMT protein can only be used for a single removal of one methyl group from the $\mathrm{O}^{6}$ position of



guanine. The conformational change of the MGMT protein by accepting the methyl group will subsequently target it for degradation through the ubiquitin proteolytic pathway [26].

\section{Non-homologous end joining}

Repair of double strand breaks (DSB), in which both strands of the double helix are damaged, can be accomplished by two different pathways of which non-homologous end joining (NHEJ) is one. DSBs are more difficult to repair than SSBs and as such require a more elaborate method of repair. DSBs are also inherently more cytotoxic than any other DNA damage. NHEJ is an error-prone pathway as it uses no homology (such as the sister chromatid) or very little for its repair function, potentially causing deletions and/or insertions [27]. The first protein to be recruited and bound to a DSB lesion is the Ku heterodimer and serves as a docking station for other additional proteins required for NHEJ. The Artemis/DNA-PKcs complex, of which the Artemis protein functions as an endonuclease, excises any damaged nucleotides at either DNA end if necessary $[\mathbf{2 8 , 2 9 ]}$. Polymerases $\mu$ and $\lambda$ are then able to fill the gaps at both the 5 '-end and 3 '-end overhang with newly synthesized DNA. Ligase, as the final step, is executed by a complex consisting of XLF, XRCC4, and DNA Ligase IV [30] (Figure 4A).

\section{Homologous recombination repair}

The other pathway able to repair DSB lesions is the homologous recombination (HR) pathway. Unlike NHEJ, HR uses an undamaged DNA template of either a sister chromatid or 
Julsing et al. Oncology Discovery 2014,

A

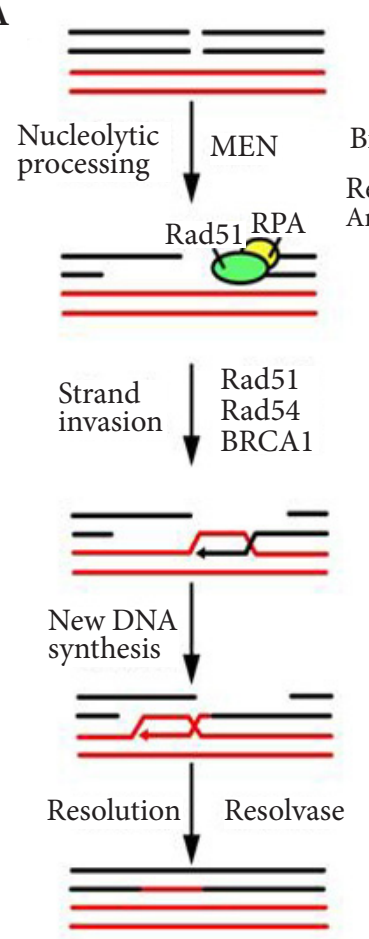

B


New DNA synthesis

Ligation

Pol $\mu$ and $\lambda$

XLF, XRCC4

Ligase IV

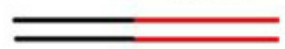

Figure 4. Simplified overviews of non-homologous end joining (NHEJ) and homologous recombination (HR) repair (modified Illustration of [30]). (A) In HR repair, the MRN complex consisting of the proteins Mre11, Rad50 and Nbs1, binds to both ends of the break which are subsequently processed into 3' ssDNA. The ssDNA end is coated with DNA replication protein A (RPA), after which RAD51 nucleoprotein filament is assembled, which replaces the RPA-coated ssDNA ends, performs homology sequence searching, mediates strand invasion and promotes DNA strand exchange. The recombining partner strands are seperated by the enzyme Resolvase. (B) During NHEJ the first proteins to bind to the break is the Ku-heterodimer, serving as a docking station for additional proteins. The Artemis/DNA-PKcs complex excises any damaged bases on either end of the break. Polymerases $\mu$ and $\lambda$ then synthesize new DNA and XLF, XRCC4 and Ligase IV seal the seams.

homologous chromosome to repair the damaged strands, leading to reestablishment of the original sequence relatively error-free [31]. After the occurrence of a DSB, the MRN complex consisting of the proteins Mre11, Rad50 and Nbs1, binds to both ends of the break which are subsequently processed into 3' ssDNA by CtIP-mediated nuclease activity [32,33]. The ssDNA end is coated with DNA replication protein A (RPA), after which RAD51 nucleoprotein filament is assembled, which replaces the RPA-coated ssDNA ends, performs homology sequence searching, mediates strand invasion and promotes DNA strand exchange $[34,35]$. Once the homologous DNA has been identified, the damaged DNA strand invades the undamaged DNA duplex with the help of Rad54 in a process referred to as DNA strand exchange [36]. A DNA polymerase then extends the $3^{\prime}$ end of the invading strand and subsequent ligation

by DNA Ligase I yields a hetero-duplexed DNA structure. Completing the recombination requires the separation of the recombining partners by the enzyme Resolvase. This recombination intermediate is resolved and the precise, errorfree correction of the DSB is completed (Figure 4B).

\section{DNA repair and cancers}

As previously mentioned the various DNA repair pathways are crucial in protecting cells against genomic instability, a characteristic of cancer development. Aberrations in the genes that are part of these pathways increase the susceptibility to cancer growth. This explains why many common cancers often possess aberrations in specific DNA repair pathways (see Table 1 ). For example, both breast and ovarian cancers often contain mutations in BRCA1 which is an important protein of the HRR pathway [37], while the MGMT gene of the direct repair pathway is often hypermethylated in glioblastomas. Susceptibility to hereditary nonpolyposis colorectal cancer (HNPCC) can in many cases be attributed to dysfunctional MLH1 and MSH2 proteins in the MMR pathway [38] and patients with a deficiency in Artemis, an important factor in NHEJ, have a predisposition to lymphomas [39]. Reduced expression of the ERCC1 protein in the NER pathway is associated with an increased risk of squamous cell carcinoma of the head and neck (SCCHN) due to the inability to sufficiently repair genetic damage induced by tobacco carcinogens such as benzo[a]pyrene diol epoxide [40]. These are only a few examples of the many cancers in which the aberration of DNA repair pathways is an important factor in their development.

Table 1. Examples of common DNA repair aberrations in cancer.

\begin{tabular}{lll}
\hline Protein & Pathway & Cancer type \\
\hline BRCA1 & HRR & Breast and ovarian cancer \\
MGMT & Direct repair & Glioblastoma \\
MLH1 and MSH2 & MMR & HNPCC \\
Artemis & NHEJ & Lymphoma \\
ERCC1 & NER & SCCHN \\
\hline
\end{tabular}

\section{Alkylating and alkylating-like agents}

Anti-cancer drugs that act by inducing lethal levels of DNA damage are often based on the process of alkylation. Alkylation is the transfer of an alkyl group $\left(\mathrm{C}_{n} \mathrm{H}_{2 n+1}\right)$ from one molecule to another. In the case of these so-called alkylating agents, the alkyl group is transferred to the 7-N position of the guanine base of DNA. Alkylating-like agents cause similar effects through a comparable process, but do not contain an alkyl group. Instead they achieve similar results by transferring other groups to the $7 \mathrm{~N}$ guanine position, such as platinum-based drugs. In both cases however, this can lead to cross-linking of the guanine bases of the two strands contained in the DNA double-helix, effectively making it impossible for the two strands to unwind and separate, in turn preventing the 
Julsing et al. Oncology Discovery 2014,

replication of DNA and thus preventing proliferation. The efficiency of these agents is however based on the assumption that DNA repair is down regulated in cancer cells. Indeed, in the case of many tumors the DNA repair has been shut down in an early stage to increase the levels of mutagenesis and genetic instability, considered one of the important characteristics of malignant transformation of cells [41]. However, it is not necessarily required and many tumors have a relatively intact DNA repair mechanism, potentially hindering the function of these alkylating agents, leading to resistance. Since the discovery of nitrogen mustards and cisplatin, examples of the very first drugs in the class of alkylating/alkylating-like agents, a great number and wide variety of new drugs have been developed in this class for a large number of different cancers.

\section{Methylation status of DNA repair genes}

As mentioned above, for alkylating/alkylating-like agents to exert their anti-cancer capabilities they require the inactivation of the DNA repair response in the cancer cells. Silencing of the genes crucial in these pathways can be accomplished by either inactivating mutations or, as described previously, by methylation of the gene promoter. Methylation patterns vary widely between normal cells and cancer cells and DNA repair genes, which are considered tumor suppressor genes (TSGs), are often methylated in varying cancer types (see Table 2). Due to this, the methylation status of certain critical DNA repair genes can be decisive whether a chemotherapy with alkylating agents will have their desired effect. This is important as a chemotherapy can have severe side effects and treating a patient who has a tumor resistant to that particular therapy will lead to an unnecessary burden for the patient and wastes both (critical) time and resources. Depending on which DNA repair gene is either methylated or unmethylated, the therapy to which resistance is obtained varies. So far, the majority of candidate predictive biomarkers belong to the group of DNA repair genes. These are often epigenetically altered in cancer and can significantly influence the response to chemotherapy [42]. The DNA repair genes of which the methylation status is considered to have a strong predictive potential will be discussed below.

\section{MGMT methylation}

MGMT is a monomeric enzyme and was first discovered in bacteria in 1977 [43]. MGMT is the only and thus crucial enzyme in the direct reversal pathway. This pathway differs from the other described DNA repair pathways in that it does not create incisions in the phosphodiester backbone to repair the DNA strand. Its main repair function is the removal of $\mathrm{O}^{6}$ methylguanine adducts, although it is also able to remove other alkyl adducts. As such MGMT prevents the genotoxic effect of $\mathrm{O}^{6}$-alkylguanine adducts produced by exogenous and endogenous alkylators in cells. As previously mentioned, the removal of adducts by MGMT is considered stoichiometric
Table 2. Examples of methylated DNA repair genes in cancer.

\begin{tabular}{|c|c|c|c|}
\hline Repair athway & Gene & Cancer type & Reference \\
\hline \multirow{5}{*}{$\begin{array}{l}\text { Base excision } \\
\text { repair }\end{array}$} & MBD4 & Multiple myeloma & {$[98]$} \\
\hline & & Colorectal cancer & [99] \\
\hline & & Ovarian cancer & [99] \\
\hline & TDG & Multiple myeloma & {$[98]$} \\
\hline & OGG1 & Papillary thyroid cancer & {$[100]$} \\
\hline \multirow{4}{*}{$\begin{array}{l}\text { Nucleotide } \\
\text { excision repair }\end{array}$} & XPC & Bladder cancer & {$[101]$} \\
\hline & & Lung cancer & {$[102]$} \\
\hline & RAD23A & Multiple myeloma & {$[103]$} \\
\hline & ERCC1 & Glioma & {$[93,94]$} \\
\hline \multirow{12}{*}{$\begin{array}{l}\text { Mismatch } \\
\text { repair }\end{array}$} & MLH1 & Sporadic colorectal cancer & {$[104]$} \\
\hline & & Colon cancer & {$[105]$} \\
\hline & & Sporadic endometrial cancer & {$[106]$} \\
\hline & & Gastric cancer & {$[107,108]$} \\
\hline & & Ovarian cancer & {$[109,110]$} \\
\hline & & Acute myeloid leukemia & {$[111]$} \\
\hline & & Non-small cell lung cancer & {$[112]$} \\
\hline & & $\begin{array}{l}\text { Head and neck squamous cell } \\
\text { carcinoma }\end{array}$ & {$[113,114]$} \\
\hline & & Oral squamous cell carcinoma & {$[115]$} \\
\hline & MSH2 & Non-small cell lung cancer & {$[112]$} \\
\hline & & Oral squamous cell carcinoma & {$[115]$} \\
\hline & & Ovarian cancer & [110] \\
\hline \multirow[t]{7}{*}{ Direct repair } & MGMT & Colon cancer & {$[116]$} \\
\hline & & Glioblastoma & [53] \\
\hline & & Gastric carcinoma & {$[117]$} \\
\hline & & Non-small cell lung cancer & {$[118]$} \\
\hline & & Small cell lung cancer & [54] \\
\hline & & $\begin{array}{l}\text { Head and neck squamous cell } \\
\text { carcinoma }\end{array}$ & [119] \\
\hline & & Cervical cancer & {$[120]$} \\
\hline $\begin{array}{l}\text { Non- } \\
\text { homologous } \\
\text { end joining }\end{array}$ & XRCC5 & Non-small cell lung cancer & {$[121]$} \\
\hline \multirow{6}{*}{$\begin{array}{l}\text { Homologous } \\
\text { recombination }\end{array}$} & BRCA1 & Breast cancer & {$[75]$} \\
\hline & & Non-small cell lung cancer & {$[121]$} \\
\hline & & Ovarian cancer & {$[122]$} \\
\hline & & Uterine leiomyosarcoma & {$[123]$} \\
\hline & & Gastric cancer & {$[124]$} \\
\hline & & Bladder cancer & {$[125]$} \\
\hline
\end{tabular}

and thus the number of adducts removed is limited by the amount of MGMT present in the cells and the rate at which it is synthesized.

\section{MGMT expression and resistance to alkylating agents}

MGMT is ubiquitously expressed in normal human tissues, but expression levels differ widely between tissues. Many human 
Julsing et al. Oncology Discovery 2014,

tumors express MGMT as well, but a fraction of gliomas lacks any detectable expression of MGMT as observed in multiple studies [44-46]. Silencing of genes in tumors is often achieved by hypermethylation of $\mathrm{CpG}$ islands in their promoter regions. Indeed, the promoter region of MGMT has been found to be methylated in human tumors lacking its expression $[47,48]$. It is well established that expression of MGMT leads to resistance against alkylating agents such as temozolomide (TMZ), streptozotocin, bis-chloroethylnitrosourea (BCNU, Carmustine) and CCNU in glioma cell lines [49-51] and xenografts [52]. Glioma patients with methylated MGMT promoter were more sensitive to BCNU than those with unmethylated MGMT, showing a $64 \%$ and $4 \%$ response rate (RR) respectively [53]. A phase II trial of TMZ in patients with small cell lung cancer showed that patients with a methylated MGMT promoter had a better response compared to those with unmethylated MGMT (38\% vs. 7\%) [54]. Especially TMZ is an important alkylating agent for chemotherapeutic treatment of patients suffering both high- and low grade brain tumors. TMZ is an alkylating agent which adds a methyl group to guanine on the $\mathrm{O}^{6}$ position. These $\mathrm{O}^{6}$-methylguanine adducts induces cytotoxicity by causing DNA polymerases to insert a thymidine opposite the adducts during DNA replication instead of a proper cytidine. This is an erroneous pairing of nucleotides and as such recruits MMR. The MMR excises a short strand of newly synthesized DNA including the erroneous thymidine, leaving a single strand gap behind. DNA polymerases attempt to repair this gap by filling it with newly synthesized DNA, reintroducing the mismatched thymidine opposite the $\mathrm{O}^{6}$-methylguanine adduct and subsequently requires MMR again. The continuous failing at removing the erroneous pairing will result in a permanent single strand gap that will cause a DSB during the DNA replication in the following S-phase, which induces apoptosis of the cell [55]. As can be concluded from this event, the MMR pathway can be a crucial factor in resistance to methylating agents besides MGMT activity. Indeed, for epigenetic silencing of MGMT to prevent resistance to TMZ of gliomas, it requires the MMR pathway to be functional (Figure 5).

\section{Reversal of MGMT induced resistance}

Given that is has been established that MGMT expression is inversely related with resistance to alkylating agents, there has been an increasing focus on discovering possible inhibitors of its activity to reduce and potentially reverse this resistance in tumors [56]. Specifically, the removal of alkyl adducts by MGMT being a stoichiometric reaction has generated interest in researching pseudosubstrate agents that function as inhibitors by depleting MGMT in tumor cells during chemotherapy based on alkylating agents. The most promising of these pseudosubstrate agents so far are $\mathrm{O}^{6}$-benzylguanine $\left(\mathrm{O}^{6}-\mathrm{BG}\right)$ and $\mathrm{O}^{6}$-(4-bromothenyl)guanine $\left(\mathrm{O}^{6}-\mathrm{BTG}\right.$, Lomeguatrib). Both MGMT inhibitors have entered phase I and II clinical trials. The safety and toxicity of utilizing $\mathrm{O}^{6}$-BG for MGMT depletion

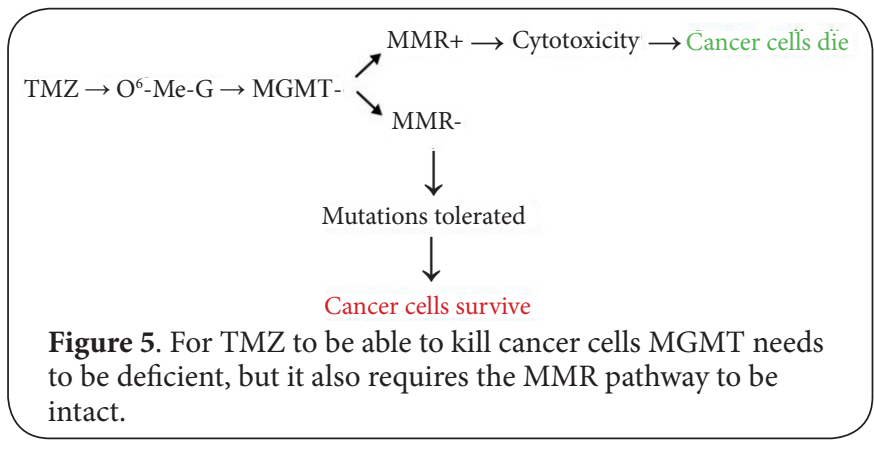

to augment the cytotoxicity of alkylating agents has been evaluated in several phase II clinical trials spanning multiple tumor types and grades (see Table 3). One phase II study of $\mathrm{O}^{6}-\mathrm{BG}$ in combination with $\mathrm{TMZ}$ in patients with glioblastoma multiforme and anaplastic glioma resulted in a $3 \%$ and $16 \%$ response rate, respectively [57]. This combination of $\mathrm{O}^{6}$-BG and TMZ was also studied in pediatric patients with recurrent or progressive high-grade gliomas ( $4 \%$ response rate) and brainstem gliomas (0\% response rate) [58]. Combining $\mathrm{O}^{6}$-BG with $\mathrm{BCNU}$ as a treatment for patients with multiple myeloma led to an overall response rate of $27 \%$ including 1 compete response and 3 partial responses [59]. In another study this same combined treatment led to no complete or partial responses in 18 patients with nitrosourea-resistant recurrent or progressive malignant glioma [60]. No response was observed in patients with advanced soft tissue sarcoma either after treatment with a combination of $\mathrm{O}^{6}-\mathrm{BG}$ and BCNU [61]. Treatment of patients with advanced melanoma with the combination of $\mathrm{O}^{6}-\mathrm{BG}$ and $\mathrm{BCNU}$ resulted in a $5 \%$ response rate [62].

Besides $\mathrm{O}^{6}-\mathrm{BG}$, the only other inactivator of MGMT that has entered clinical trials is $\mathrm{O}^{6}$-BTG (see Table 3 ). It is regarded as the most potent MGMT inactivator with an $\mathrm{IC}_{50}$ (concentration needed to reduce MGMT activity by $50 \%$ ) of $3.4 \mathrm{nM}$ compared to the $\mathrm{IC}_{50}$ of $180 \mathrm{nM}$ of $\mathrm{O}^{6}$-BG [63]. In one randomized phase II trial, patients with metastatic cutaneous melanoma were treated with either a combination of $\mathrm{O}^{6}$-BTG and TMZ (17.3\% RR) or TMZ alone (13.5\% RR) [64]. Another phase II study in patients with metastatic colorectal carcinoma evaluated the effect of a combination of $\mathrm{O}^{6}$-BTG and TMZ or TMZ alone as treatment, both showed no response in all patients [65]. A third phase II study studied the MGMT depletion in patients with metastatic melanoma after treatment with the combination of $\mathrm{O}^{6}-\mathrm{BTG}$ and TMZ or TMZ alone, showing a slow and incomplete inactivation following treatment with $\mathrm{TMZ}$ and more rapid, total, depletion with $\mathrm{O}^{6}$-BTG and TMZ combined [66].

Up to now, the results of these phase ll trials of MGMT inhibitors have been disappointing so far. Although there are many indicators that MGMT is a major resistance factor in many human tumors to multiple chemotherapeutic agents, there has been no convincing evidence so far that the strategy of reversing the resistance by depleting MGMT improves the outcome in cancer patients treated with these agents. The 
Julsing et al. Oncology Discovery 2014,

http://www.hoajonline.com/journals/pdf/2052-6199-2-3.pdf

doi: $10.7243 / 2052-6199-2-3$

Table 3. Clinical phase II studies with $\mathrm{O}^{6}-\mathrm{BG}$ and $\mathrm{O}^{6}-\mathrm{BTG}$.

\begin{tabular}{|c|c|c|c|}
\hline $\begin{array}{l}\text { Drug } \\
\text { combination }\end{array}$ & Cancer type & Results & Reference \\
\hline \multicolumn{4}{|c|}{ Clinical phase II studies with $\mathrm{O}^{6}$-BG } \\
\hline $\mathrm{TMZ}+\mathrm{O}^{6}-\mathrm{BG}$ & $\begin{array}{l}\text { Glioblastoma } \\
\text { multiforme } \\
\text { Anaplastic glioma }\end{array}$ & $\begin{array}{l}3 \% \mathrm{RR} \\
16 \% \mathrm{RR}\end{array}$ & [57] \\
\hline $\mathrm{TMZ}+\mathrm{O}^{6}-\mathrm{BG}$ & $\begin{array}{l}\text { Progressive high-grade } \\
\text { glioma } \\
\text { Brainstem glioma }\end{array}$ & $\begin{array}{l}4 \% \mathrm{RR} \\
0 \% \mathrm{RR}\end{array}$ & {$[58]$} \\
\hline $\mathrm{BCNU}+\mathrm{O}^{6}-\mathrm{B}$ & Multiple myeloma & $27 \% \mathrm{RR}$ & [59] \\
\hline $\mathrm{BCNU}+\mathrm{O}^{6}-\mathrm{BG}$ & $\begin{array}{l}\text { Recurrent or } \\
\text { progressive glioma }\end{array}$ & $0 \% \mathrm{RR}$ & {$[60]$} \\
\hline $\mathrm{BCNU}+\mathrm{O}^{6}-\mathrm{BG}$ & $\begin{array}{l}\text { Advanced soft tissue } \\
\text { sarcoma }\end{array}$ & $0 \% \mathrm{RR}$ & {$[61]$} \\
\hline $\mathrm{BCNU}+\mathrm{O}^{6}-\mathrm{BG}$ & Advanced melanoma & $5 \% \mathrm{RR}$ & {$[62]$} \\
\hline \multicolumn{4}{|c|}{ Clinical phase II studies with $\mathrm{O}^{6}$-BTG } \\
\hline $\begin{array}{l}\text { TMZ alone } \\
\text { TMZ+O'6-BTG }^{6}\end{array}$ & $\begin{array}{l}\text { Metastatic cutaneous } \\
\text { melanoma }\end{array}$ & $\begin{array}{l}13.5 \% \mathrm{RR} \\
17.3 \% \mathrm{RR}\end{array}$ & {$[64]$} \\
\hline $\begin{array}{l}\text { TMZ alone } \\
\text { TMZ+O'-BTG }\end{array}$ & $\begin{array}{l}\text { Metastatic colorectal } \\
\text { carcinoma }\end{array}$ & $\begin{array}{l}0 \% \mathrm{RR} \\
0 \% \mathrm{RR}\end{array}$ & {$[65]$} \\
\hline $\begin{array}{l}\text { TMZ alone } \\
\text { TMZ+O'- } 1 \text { T }\end{array}$ & Metastatic melanoma & $\begin{array}{l}\text { Partial MGMT } \\
\text { depletion } \\
\text { Complete } \\
\text { MGMT } \\
\text { depletion }\end{array}$ & {$[66]$} \\
\hline
\end{tabular}

lack of encouraging phase II results in reversing the resistance by the aforementioned treatment combinations might be due to multiple factors. First, dose reductions in TMZ were necessary to avoid hematologic toxicity when combined with $\mathrm{O}^{6}-\mathrm{BG}$ or $\mathrm{O}^{6}-\mathrm{BTG}$. This could be an underlying factor for its failure to properly sensitize the tumors to the treatment. Alternative methods of administration of either alkylating agents or MGMT inactivators could be a potential solution in reducing system toxicity, enabling the use of higher doses. Second, the dosing regimen of TMZ in combination with an MGMT inactivator is most likely not optimal yet. Thirdly, some of the investigated tumor types did not respond to TMZ alone either and it has not been demonstrated that their resistance is related to MGMT overexpression. Addressing these issues could lead to better results in sensitizing tumors to TMZ and other alkylating agents.

\section{BRCA1 methylation}

The breast cancer 1 (BRCA1) gene was first identified in 1994 [37]. It produces the breast cancer type 1 susceptibility protein which is expressed in the cells of breast and other tissues and functions in the BRCA-Fanconi anemia pathway. This protein has an important role in repair of DSB in DNA by forming a large multi-subunit protein complex known as the BRCA1associated genome surveillance complex (BASC). This large protein complex, also consisting of other tumor suppressors, DNA damage sensors and signal transducers, participates in the HR mechanism of DNA DSB repair. As mentioned earlier, $H R$ repair uses an undamaged DNA template of either a sister chromatid or homologous chromosome to repair the damaged strands [31]. In nuclear foci in mitotic cells BRCA1 associates and colocalizes with RAD51, a protein involved in the search for homology and strand pairing stages of the HR repair process. This was one of the earliest indications that BRCA 1 functions in HR repair [67]. Although the exact mechanisms by which BRCA1 functions in HR are not entirely clear yet, studies have suggested 2 possible roles: It promotes via interaction with CtBP-interacting protein (CtIP) [68], and it might act as a recombination mediator/comediator by interacting with RAD51 [69]. It is generally believed that BRCA1 maintains genomic stability by promoting error free HR and suppressing error prone NHEJ, protecting the DNA from mutagenesis due to error prone nonhomologous DSB repair [70-72]. Indeed, loss of function of BRCA1, whether due to hypermethylation or other means, is a major contributing factor in tumorigenesis.

\section{BRCA1 methylation in cancer}

Promoter hypermethylation of the BRCA1 gene has a high frequency of occurrence in both ovarian cancer and sporadic breast cancer. Due to the important role of BRCA1 in HR repair of DNA DSBs, loss of its function has been associated with resistance to platinum-based chemotherapy. These platinum containing drugs belong to the alkylating-like agents as they attach platinum instead of alkyl groups as adducts on DNA. Loss of BRCA1 due to an inactivating mutation has been associated with increased sensitivity to these platinum containing alkylating-like agents in patients with ovarian cancer [73]. As hypermethylation of gene promoter regions silence that particular gene, this should cause loss of function as well, however, research on the methylation status of BRCA1 is sparse. A study has shown that methylation of BRCA1 sensitizes breast cancer cells to PARP inhibitors, another class of drugs used for treating breast cancer patients [74]. Of 167 patients with breast cancer that received adjuvant chemotherapy in the form of PARP inhibitors, patients with BRCA1-methylated tumors had a superior 10 -year disease-free survival $(78 \%$ versus $55 \%$, $\mathrm{P}=0.009$ ) and 10 -year disease-specific survival ( $85 \%$ versus $69 \%, P=0.024)$ than those with BRCA1-unmethylated tumors [75]. BRCA1 hypermethylation has also been associated with a significant increase in median PFS of ovarian cancer patients receiving adjuvant platinum-taxane-based chemotherapy [76]. Another recent study observed that, as is the case with tumors containing BRCA1 inactivating mutations, breast and ovarian cancers containing hypermethylated BRCA1 are more sensitive to platinum-based agents such as cisplatin as well [77]. This suggests that methylation of BRCA1 prevents the HR pathway from successfully repairing the DNA damage induced by platinum-based agents. A study analyzing the DNA methylation status of various genes involved in the HR repair pathway in breast cancer samples, found only hy-permethylation of BRCA1 and RNF8 to be associated with chemosensitivity [78] 
Julsing et al. Oncology Discovery 2014,

http://www.hoajonline.com/journals/pdf/2052-6199-2-3.pdf

doi: $10.7243 / 2052-6199-2-3$

\section{MLH1 methylation}

MLH1 is part of the heterodimeric MLH1-PMS1 protein crucial for creating incisions in DNA during MMR, a repair pathway that corrects replication errors due to the incorporation of the wrong nucleotide (a mismatch), nucleotide deletions and insertions. These incisions are made on either the $3^{\prime}$-or $5^{\prime}$-end of the lesion containing the mismatch after which the ssDNA segment including the mismatch is removed by EXO1, an exonuclease. This enables that the resulting gap can be filled up with newly synthesized DNA that correctly pairs with the already existing DNA strand. As briefly mentioned earlier, the MMR pathway plays an important role in the mechanism by which TMZ attempts to kill cancer cells.

\section{MLH1 methylation in cancer}

Methylation of MLH1 is not uncommon in colorectal cancers, as approximately $15 \%$ shows micro satellite instability due to methylation of this MMR gene [79]. However, not only does the methylation of MLH1 promote tumorigenesis, it also enables resistance of these tumors to Fluorouracil (5-FU), a widely used chemotherapeutic agent for treating colorectal cancers [80]. Indeed, while promoter hypermethylation of all other discussed DNA repair genes prevent/reverse chemotherapy resistance, hypermethylation of MLH1 promotes resistance to chemotherapeutic agents instead.

Besides conferring resistance to 5-FU, MLH1 promoter methylation also promotes resistance to $T M Z$ due to the role of the MMR pathway in how TMZ kills cancer cells. A study in ovarian cancer cell lines showed that inactivation of MGMT and demethylation of MLH1 combined had a greater sensitizing effect of these cells to TMZ than either MGMT inactivation or MLH1 demethylation alone [81]. In another study, using patient material consisting of resected primary tumors of advanced epithelial ovarian cancer, it was shown that methylation of MLH1 is a major molecular cause of acquired resistance to platinum-based chemotherapy as well [82]. This corresponds with an earlier study that suggested methylation of the MLH1 promoter to be a possible mechanism for cisplatin-resistance in ovarian cancer [83]. MLH1 methylation has recently also been associated with oxaliplatin-resistance in gastric cancer patients [84], although repair of oxaliplatin caused DNA adducts is usually considered to be performed by the ERCC 1 complex. The promotion of resistance by MLH1 methylation is due the requirement of MMR to be intact for platinum-based anti-cancer drugs to effectively kill cancer cells. Similar to the methylation adduct added by $\mathrm{TMZ}$, platinum adducts cause misincorporation of a base opposite the adduct during replication. This is recognized by the MMR system that subsequently attempts futile repair. This will generate a signal that triggers apoptosis [85].

\section{Reversal of methylated MLH1 induced resistance}

Considering that the resistance to several chemotherapeutic agents is conferred by methylation of the promoter region of the MLH1 gene, reversal of this resistance should be achievable by demethylating these promoter regions. In general, demethylation of DNA is accomplished by inhibiting the DNMTs that have been discussed earlier. As has been mentioned, these DNMTs are crucial for both establishing the methylation pattern (DNMT3a and DNMT3b) as well as maintaining it through DNA replication (DNMT1). Demethylation of DNA is performed by so called DNA methyltransferase inhibitors (DNMTis) or demethylating agents. The two best studied DNA methyltransferase inhibitors are the azanucleosides azacytidine (5-azacytidine) and decitabine (5-aza-2'-deoxycytidine, DAC). These two DNMTis have been approved for clinical use in treatment of myelodysplastic syndromes and low-blast count $\mathrm{AML}$ and have shown improvements in survival of patients [86].

An in vitro study showed that resistance to 5-FU can be overcome by re-expression of the MLH1 protein through DAC-induced demethylation in hypermethylated colorectal cancer cell lines [87]. Another study showed that treatment with DAC of ovarian and colon tumor xenografts that contain hypermethylated $\mathrm{MLH} 1$ promoters reverses their resistance to varying chemotherapeutic agents, including cisplatin, TMZ and carboplatin [88]. Results of a phase II clinical trial suggest low-dose DAC alters the DNA methylation of genes, restoring sensitivity to carboplatin in platinum-resistant ovarian cancer patients, showing a positive correlation of MLH1 demethylation in tumors with PFS [89]. Although the results are encouraging, one must be cautious. While DNA methylation has a frequent occurrence in cancer cells as it is one of the major mechanisms (the other being mutations) by which genome wide gene expression is altered to facilitate transformation of normal cells into malignant cells, DNMTis are not gene specific and as such can have a genome wide demethylating effects and can lead to negative side-effects.

\section{ERCC1 methylation}

Promoter methylation of the ERCC1 gene has attracted relatively little attention compared to the MGMT, BRCA1 and MLH1 gene. ERCC1 is a crucial gene in the NER pathway, which has the ability to repair bulky DNA adducts, including platinumDNA adducts. The product of the ERCC1 gene interacts with $\mathrm{XPF}$, an endonuclease, to form the heterodimeric ERCC1-XPF protein complex, which is involved in the excision of DNAadducts by performing incisions at the $5^{\prime}$-end of the lesion.

It had already been reported that cancer cells with a deficient NER pathway have an increased sensitivity to platinum agents [90]. Indeed, considering that ERCC1 is a crucial gene for the NER pathway to function correctly, studies have found its $\mathrm{mRNA}$ /protein expression levels to have a predictive value for the resistance of cancer cells to platinum-based chemotherapies (e.g., [91,92]). Therefore it is important to understand which mechanism regulates the ERCC1 expression. Epigenetic inactivation of the ERCC1 gene by promoter hypermethylation could be a potential regulator of its expression. However, very few studies have explicitly investigated the correlation 
Julsing et al. Oncology Discovery 2014,

between ERCC1 promoter hypermethylation and therapy resistances. One study found an association of promoter methylation of ERCC 1 with cisplatin sensitivity, using 32 glioma samples [93]. This study also observed that ERCC1 promoter methylation was inversely correlated to mRNA expression. Another study investigated the relation between ERCC1 methylation and radio-sensitivity in glioma cell lines and their results indicated there is strong association of the methylation status of ERCC1 with radio-sensitivity [94]. This study also showed that demethylation of the ERCC1 promoter by using 5 -azacytidine resulted in a decrease in radio-sensitivity. Similar to alkylating agents, ionizing radiation also exerts its antitumor effect through induction of DNA damage.

\section{DNA repair gene methylation status as biomarker}

Since it is increasingly accepted that epigenetic mechanisms such as methylation may be just as important as genetic changes in the development of cancer, DNA methylation biomarkers are slowly included in cancer molecular diagnostics. There are two ways to apply the analysis of DNA methylation in cancer. First, DNA methylation has the potential to be used as a biomarker to confirm the presence or absence of a tumor as in early detection or minimal residual disease detection. Second, an already diagnosed tumor can be analyzed for prognostic or predictive methylation biomarkers. So far DNA methylation biomarkers have mainly garnered attention for potential early detection due to aberrant DNA methylation seemingly occurring in early-stage tumors. However, as the various studies described in this article have shown (Table 4), methylation of the discussed DNA repair genes could be viable biomarkers for prognostic value and for predicting chemotherapeutic responses due to their critical role in acquired chemotherapyresistance of tumors. This would enable the stratification of patients based on these biomarkers, leading to a more 'personalized' treatment of these patients. Besides potentially lessening patient burden due to better chemotherapy selection, stratification can be a critical component to change the perspective from a negative or neutral outcome to one with a positive outcome by identifying the subset of the population most likely to respond to a novel therapy.

Indeed, due to their critical role in the DNA repair pathways and their association with therapy resistances, the methylation status of these genes generally has a prognostic and predictive significance as well. For example, MGMT promoter methylation status was found to be promising prognostic biomarker in patients with glioblastoma multiforme (GBM) treated with radiation and $\mathrm{TMZ}$, as methylated patients demonstrated a median overall survival (OS) of 24.7 months, whereas unmethylated patients demonstrated a median OS of 16.2 months. Progression free survival (PFS) was also higher among methylated than among unmethylated patients (13.3 months vs. 7.8 months) [95]. This is in agreement with results of another study that showed MGMT methylation was correlated with better survival of treated GBM patients with a hazard ratio (HR)
Table 4. DNA repair gene methylation and therapy resistances in cancers.

\begin{tabular}{|c|c|c|c|c|}
\hline $\begin{array}{l}\text { DNA } \\
\text { repair } \\
\text { gene } \\
\text { methylation }\end{array}$ & Effect & $\begin{array}{l}\text { Chemothera- } \\
\text { peutic agent }\end{array}$ & Cancer type & Reference \\
\hline \multirow[t]{7}{*}{ MGMT } & Sensitizing & TMZ & Glioma & {$[50]$} \\
\hline & & & $\begin{array}{l}\text { Small cell lung } \\
\text { cancer }\end{array}$ & {$[54]$} \\
\hline & & $\mathrm{BCNU}$ & Glioma & {$[49,53]$} \\
\hline & & & Breast cancer & {$[126]$} \\
\hline & & $\mathrm{CCNU}$ & Glioma & {$[49]$} \\
\hline & & Streptozotocin & Glioma & {$[50]$} \\
\hline & & Dacarbazine & $\begin{array}{l}\text { Colorectal } \\
\text { cancer }\end{array}$ & {$[127]$} \\
\hline \multirow[t]{5}{*}{ BRCA1 } & Sensitizing & $\begin{array}{l}\text { PARP } \\
\text { inhibitors }\end{array}$ & Breast cancer & {$[74,75]$} \\
\hline & & Cisplatin & Breast cancer & {$[77]$} \\
\hline & & & Ovarian cancer & {$[77]$} \\
\hline & & Carboplatin & Breast cancer & [77] \\
\hline & & & Ovarian cancer & {$[77]$} \\
\hline \multirow[t]{5}{*}{ MLH1 } & $\begin{array}{l}\text { Resistance } \\
\text { promoting }\end{array}$ & 5-FU & $\begin{array}{l}\text { Colorectal } \\
\text { cancer }\end{array}$ & {$[80]$} \\
\hline & & TMZ & Ovarian cancer & {$[81]$} \\
\hline & & Cisplatin & Ovarian cancer & {$[82,128]$} \\
\hline & & Carboplatin & Ovarian cancer & {$[82,89]$} \\
\hline & & Oxaliplatin & Gastric cancer & {$[84]$} \\
\hline ERCC1 & Sensitizing & $\begin{array}{l}\text { Cisplatin } \\
\text { Radiotherapy }\end{array}$ & $\begin{array}{l}\text { Glioma } \\
\text { Glioma }\end{array}$ & $\begin{array}{l}{[93]} \\
{[94]}\end{array}$ \\
\hline
\end{tabular}

of 0.61 [96]. Moreover the median OS among GBM patients with methylated MGMT promoter tumors was 19 months compared with 13 months in patients with unmethylated MGMT promoter tumors and the median PFS was 8 months for the methylated MGMT promoter status compared with 6 months for the unmethylated MGMT promoter status [97]. These studies (see Table 5) show great promise in its value as prognostic biomarker, but its use as a predictive biomarker is limited. A major factor is that for a predictive biomarker to be of great value, different treatment options must exist that circumvent or reverse the resistance. For example, clinical trials with possible new treatment options such as $\mathrm{O}^{6}$-BG and $\mathrm{O}^{6}$-BTG so far showed disappointing results, making the predictive value of MGMT methylation as biomarker of limited use, while its use as a prognostic biomarker would be more sensible. Furthermore, another restriction to the clinical utilization of the methylation status of these DNA repair genes is the lack of a validated, standardized promoter methylation assay. Standardization is mainly obstructed by the lack of consensus on which technique is most manageable in clinical setting and which criteria allow an objective assessment of methylation status. Indeed, while identification of biomarkers that predict tumor response to therapy is a critical step in the 
Julsing et al. Oncology Discovery 2014,

http://www.hoajonline.com/journals/pdf/2052-6199-2-3.pdf

doi: $10.7243 / 2052-6199-2-3$

Table 5. Examples of studies showing prognostic use of MGMT methylation in glioblastoma patients.

\begin{tabular}{|c|c|c|c|c|}
\hline Cancer type & Status & $\begin{array}{l}\text { Median OS } \\
\text { (months }\end{array}$ & $\begin{array}{l}\text { Median PFS } \\
\text { (months) }\end{array}$ & Reference \\
\hline Glioblastoma & Methylated & 24.7 & 13.3 & \multirow{2}{*}[95]{} \\
\hline multiforme & Unmethylated & 16.2 & 7.8 & \\
\hline Glioblastoma & Methylated & 19 & 8 & \multirow{2}{*}{ [97] } \\
\hline multiforme & Unmethylated & 13 & 6 & \\
\hline \multicolumn{5}{|c|}{ HR } \\
\hline $\begin{array}{l}\text { Glioblastoma } \\
\text { multiforme }\end{array}$ & Methylated & 0.61 & & [96] \\
\hline
\end{tabular}

development of treatment regimens tailored to individual patients to produce optimal clinical outcomes, the clinical utility of DNA gene promoter methylation status is currently limited to providing overall prognosis estimations.

\section{Conclusion}

As can be concluded, DNA repair genes can be considered an interesting subclass of TSGs. As is the case with other TSGs, they are often epigenetically inactivated by promoter hypermethylation causing genomic instability during carcinogenesis. Epigenetic inactivation of DNA repair genes in cancer has been reported for several DNA repair pathways such as NER, direct repair, MMR and HR repair. However, while methylation of DNA repair genes is generally regarded as a negative event due to this, the same methylation of DNA repair genes sensitizes fully grown tumors to varying chemotherapeutic agents in certain cases. Indeed, methylation of DNA repair genes such as MGMT, BRCA1 and ERCC1 increase the therapeutic sensitivity of varying cancer types, providing a potential therapeutic benefit to patients. The most promising example being the increased sensitivity to the chemo-therapeutic agent TMZ due to MGMT promoter hyper methylation in patients with glioma. Surprisingly however, epigenetic inactivation of the MLH1 gene, part of the MMR pathway, has been associated with an increase in resistance of cancer cells to varying chemotherapeutic agents. These findings suggest that the methylation status of these genes could be viable predictive biomarkers and subsequently enable the potential to develop personalized chemotherapeutic regimens tailored to a patient's DNA repair gene methylation status in the future. This however, requires further improvement and advancement in standardization of methylation status assays before clinically applicable.

\section{Competing interests}

The authors declare that they have no competing interests.
Authors' contributions

\begin{tabular}{|l|c|c|}
\hline Authors' contributions & JRJ & GJP \\
\hline Research concept and design & $\checkmark$ & $\checkmark$ \\
\hline Collection and/or assembly of data & $\checkmark$ & -- \\
\hline Data analysis and interpretation & $\checkmark$ & -- \\
\hline Writing the article & $\checkmark$ & $\checkmark$ \\
\hline Critical revision of the article & -- & $\checkmark$ \\
\hline Final approval of article & -- & $\checkmark$ \\
\hline
\end{tabular}

Publication history

Editors: Matthew Strout, Yale University School of Medicine, USA. Parmeet Kaur Manchanda, Ohio State University, USA. EICS: Paul J. Higgins, Albany Medical College, USA. William Chi-shing Cho, Queen Elizabeth Hospital, Hong Kong. Received: 01-Aug-2014 Final Revised: 11-Sep-2014 Accepted: 09-Oct-2014 Published: 16-Oct-2014

\section{References}

1. Miranda TB and Jones PA. DNA methylation: the nuts and bolts of repression. J Cell Physiol. 2007; 213:384-90. | Article I PubMed

2. Jones RS. Epigenetics: reversing the 'irreversible'. Nature. 2007; 450:357-9. | Article | PubMed

3. Mohandas T, Sparkes RS and Shapiro LJ. Reactivation of an inactive human $X$ chromosome: evidence for $X$ inactivation by DNA methylation. Science. 1981; 211:393-6. | Article | PubMed

4. Reik W, Collick A, Norris ML, Barton SC and Surani MA. Genomic imprinting determines methylation of parental alleles in transgenic mice. Nature. 1987; 328:248-51. I Article I PubMed

5. Woodcock DM, Lawler CB, Linsenmeyer ME, Doherty JP and Warren WD. Asymmetric methylation in the hypermethylated CpG promoter region of the human L1 retrotransposon. J Biol Chem. 1997; 272:78106. | Article | PubMed

6. Takai D and Jones PA. Comprehensive analysis of $\mathrm{CpG}$ islands in human chromosomes 21 and 22. Proc Natl Acad Sci U S A. 2002; 99:3740-5. | Article I PubMed Abstract | PubMed Full Text

7. Jones PA and Liang G. Rethinking how DNA methylation patterns are maintained. Nat Rev Genet. 2009; 10:805-11. | Article I PubMed Abstract | PubMed Full Text

8. Okano M, Bell DW, Haber DA and Li E. DNA methyltransferases Dnmt3a and Dnmt3b are essential for de novo methylation and mammalian development. Cell. 1999; 99:247-57. | Article | PubMed

9. Robert MF, Morin S, Beaulieu N, Gauthier F, Chute IC, Barsalou A and MacLeod AR. DNMT1 is required to maintain CpG methylation and aberrant gene silencing in human cancer cells. Nat Genet. 2003; 33:615. | Article | PubMed

10. Bostick M, Kim JK, Esteve PO, Clark A, Pradhan S and Jacobsen SE. UHRF1 plays a role in maintaining DNA methylation in mammalian cells. Science. 2007; 317:1760-4. | Article | PubMed

11. Ehrlich M. DNA methylation in cancer: too much, but also too little. Oncogene. 2002; 21:5400-13. | Article | PubMed

12. Baur AS, Shaw P, Burri N, Delacretaz F, Bosman FT and Chaubert P. Frequent methylation silencing of p15(INK4b) (MTS2) and p16(INK4a) (MTS1) in B-cell and T-cell lymphomas. Blood. 1999; 94:1773-81. | Article I PubMed

13. Graff JR, Herman JG, Lapidus RG, Chopra H, Xu R, Jarrard DF, Isaacs WB, Pitha PM, Davidson NE and Baylin SB. E-cadherin expression is silenced by DNA hypermethylation in human breast and prostate carcinomas. Cancer Res. 1995; 55:5195-9. I Article I PubMed

14. Qian J, Wang YL, Lin J, Yao DM, Xu WR and Wu CY. Aberrant methylation of the death-associated protein kinase 1 (DAPK1) CpG island in chronic myeloid leukemia. Eur J Haematol. 2009; 82:119-23. | Article I PubMed 
Julsing et al. Oncology Discovery 2014,

http://www.hoajonline.com/journals/pdf/2052-6199-2-3.pdf

doi: $10.7243 / 2052-6199-2-3$

15. Hanahan D and Weinberg RA. Hallmarks of cancer: the next generation. Cell. 2011; 144:646-74. I Article I PubMed

16. Middleton MR and Margison GP. Improvement of chemotherapy efficacy by inactivation of a DNA-repair pathway. Lancet Oncol. 2003; 4:37-44. | Article | PubMed

17. Lindahl T. Instability and decay of the primary structure of DNA. Nature. 1993; 362:709-15. | Article | PubMed

18. van Loon B, Markkanen $E$ and Hubscher $U$. Oxygen as a friend and enemy: How to combat the mutational potential of 8-oxo-guanine. DNA Repair (Amst). 2010; 9:604-16. | Article | PubMed

19. Braithwaite EK, Prasad R, Shock DD, Hou EW, Beard WA and Wilson $\mathrm{SH}$. DNA polymerase lambda mediates a back-up base excision repair activity in extracts of mouse embryonic fibroblasts. J Biol Chem. 2005; 280:18469-75. | Article | PubMed

20. Huang JC, Svoboda DL, Reardon JT and Sancar A. Human nucleotide excision nuclease removes thymine dimers from DNA by incising the 22nd phosphodiester bond 5' and the 6th phosphodiester bond 3' to the photodimer. Proc Natl Acad Sci U S A. 1992; 89:3664-8. | Article | PubMed Abstract | PubMed Full Text

21. de Laat WL, Jaspers NG and Hoeijmakers JH. Molecular mechanism of nucleotide excision repair. Genes Dev. 1999; 13:768-85. | Article | wPubMed

22. Iyer RR, Pluciennik A, Burdett $V$ and Modrich PL. DNA mismatch repair: functions and mechanisms. Chem Rev. 2006; 106:302-23. I Article | PubMed

23. Mishina $Y$, Duguid EM and He C. Direct reversal of DNA alkylation damage. Chem Rev. 2006; 106:215-32. | Article I PubMed Abstract PubMed Full Text

24. Saffhill R, Margison GP and O'Connor PJ. Mechanisms of carcinogenesis induced by alkylating agents. Biochim Biophys Acta. 1985; 823:111-45. | Article | PubMed

25. Ochs $\mathrm{K}$ and Kaina $\mathrm{B}$. Apoptosis induced by DNA damage 06methylguanine is $\mathrm{Bcl}-2$ and caspase-9/3 regulated and Fas/caspase-8 independent. Cancer Res. 2000; 60:5815-24. I Article I PubMed

26. Srivenugopal KS, Yuan XH, Friedman HS and Ali-Osman F. Ubiquitination-dependent proteolysis of O6-methylguanine-DNA methyltransferase in human and murine tumor cells following inactivation with 06-benzylguanine or 1,3-bis(2-chloroethyl)-1nitrosourea. Biochemistry. 1996; 35:1328-34. I Article I PubMed

27. Lieber MR. The mechanism of human nonhomologous DNA end joining. J Biol Chem. 2008; 283:1-5. | Article | PubMed

28. Dahm K. Functions and regulation of human artemis in double strand break repair. J Cell Biochem. 2007; 100:1346-51. | Article I PubMed

29. Ma Y, Pannicke U, Schwarz K and Lieber MR. Hairpin opening and overhang processing by an Artemis/DNA-dependent protein kinase complex in nonhomologous end joining and $\mathrm{V}(\mathrm{D}) \mathrm{J}$ recombination. Cell. 2002; 108:781-94. | Article | PubMed

30. Weterings $E$ and Chen DJ. The endless tale of non-homologous endjoining. Cell Res. 2008; 18:114-24. | Article | PubMed

31. Sargent RG, Brenneman MA and Wilson JH. Repair of site-specific double-strand breaks in a mammalian chromosome by homologous and illegitimate recombination. Mol Cell Biol. 1997; 17:267-77. | Article | PubMed Abstract | PubMed Full Text

32. Limbo O, Chahwan C, Yamada Y, de Bruin RA, Wittenberg $C$ and Russell P. Ctp1 is a cell-cycle-regulated protein that functions with Mre11 complex to control double-strand break repair by homologous recombination. Mol Cell. 2007; 28:134-46. | Article | PubMed Abstract I PubMed Full Text

33. Takeda S, Nakamura K, Taniguchi $Y$ and Paull TT. Ctp1/CtIP and the MRN complex collaborate in the initial steps of homologous recombination. Mol Cell. 2007; 28:351-2. I Article I PubMed

34. Golub EI, Gupta RC, Haaf T, Wold MS and Radding CM. Interaction of human rad51 recombination protein with single-stranded DNA binding protein, RPA. Nucleic Acids Res. 1998; 26:5388-93. | Article | PubMed Abstract | PubMed Full Text

35. Sung $P$, Krejci L, Van Komen $S$ and Sehorn MG. Rad51 recombinase and recombination mediators. J Biol Chem. 2003; 278:42729-32. | Article | PubMed

36. Solinger JA and Heyer WD. Rad54 protein stimulates the postsynaptic phase of Rad51 protein-mediated DNA strand exchange. Proc Natl Acad Sci U S A. 2001; 98:8447-53. | Article | PubMed Abstract | PubMed Full Text

37. Miki Y, Swensen J, Shattuck-Eidens D, Futreal PA, Harshman K, Tavtigian S, Liu Q, Cochran C, Bennett LM, Ding W and et al. A strong candidate for the breast and ovarian cancer susceptibility gene BRCA1. Science. 1994; 266:66-71. | Article | PubMed

38. Umar A, Boland CR, Terdiman JP, Syngal S, de la Chapelle A, Ruschoff J, Fishel R, Lindor NM, Burgart LJ, Hamelin R, Hamilton SR, Hiatt RA, Jass J, Lindblom A, Lynch HT, Peltomaki P, Ramsey SD, Rodriguez-Bigas MA, Vasen HF, Hawk ET, Barrett JC, Freedman AN and Srivastava S. Revised Bethesda Guidelines for hereditary nonpolyposis colorectal cancer (Lynch syndrome) and microsatellite instability. J Natl Cancer Inst. 2004; 96:261-8. | Article | PubMed Abstract | PubMed Full Text

39. Moshous D, Pannetier C, Chasseval Rd R, Deist FI F, Cavazzana-Calvo M, Romana S, Macintyre E, Canioni D, Brousse N, Fischer A, Casanova $\mathrm{JL}$ and Villartay JP. Partial T and B lymphocyte immunodeficiency and predisposition to lymphoma in patients with hypomorphic mutations in Artemis. J Clin Invest. 2003; 111:381-7. | Article | PubMed Abstract | PubMed Full Text

40. Cheng L, Sturgis EM, Eicher SA, Spitz MR and Wei Q. Expression of nucleotide excision repair genes and the risk for squamous cell carcinoma of the head and neck. Cancer. 2002; 94:393-7 7. I Article | PubMed

41. Shih IM, Zhou W, Goodman SN, Lengauer C, Kinzler KW and Vogelstein $B$. Evidence that genetic instability occurs at an early stage of colorectal tumorigenesis. Cancer Res. 2001; 61:818-22. | Article | PubMed

42. Hegi ME, Sciuscio D, Murat A, Levivier M and Stupp R. Epigenetic deregulation of DNA repair and its potential for therapy. Clin Cancer Res. 2009; 15:5026-31. | Article | PubMed

43. Samson $L$ and Cairns J. A new pathway for DNA repair in Escherichia coli. Nature. 1977; 267:281-3. | PubMed

44. Silber JR, Blank A, Bobola MS, Ghatan S, Kolstoe DD and Berger MS. O6methylguanine-DNA methyltransferase-deficient phenotype in human gliomas: frequency and time to tumor progression after alkylating agent-based chemotherapy. Clin Cancer Res. 1999; 5:807-14. | Article | PubMed

45. Silber JR, Bobola MS, Ghatan S, Blank A, Kolstoe DD and Berger MS. 06-methylguanine-DNA methyltransferase activity in adult gliomas: relation to patient and tumor characteristics. Cancer Res. 1998; 58:1068-73. | Article | PubMed

46. Wiewrodt D, Nagel G, Dreimuller N, Hundsberger T, Perneczky A and Kaina B. MGMT in primary and recurrent human glioblastomas after radiation and chemotherapy and comparison with p53 status and clinical outcome. Int J Cancer. 2008; 122:1391-9. | Article | PubMed

47. Qian XC and Brent TP. Methylation hot spots in the $5^{\prime}$ flanking region denote silencing of the 06-methylguanine-DNA methyltransferase gene. Cancer Res. 1997; 57:3672-7. I Article I PubMed

48. Watts GS, Pieper RO, Costello JF, Peng YM, Dalton WS and Futscher BW. Methylation of discrete regions of the 06-methylguanine DNA methyltransferase (MGMT) CpG island is associated with heterochromatinization of the MGMT transcription start site and silencing of the gene. Mol Cell Biol. 1997; 17:5612-9. | Article | PubMed Abstract | PubMed Full Text

49. Bobola MS, Berger MS and Silber JR. Contribution of O6methylguanine-DNA methyltransferase to resistance to 1,3-(2-chloroethyl)-1-nitrosourea in human brain tumor-derived cell lines. Mol Carcinog. 1995; 13:81-8. I PubMed

50. Bobola MS, Tseng SH, Blank A, Berger MS and Silber JR. Role of 06-methylguanine-DNA methyltransferase in resistance of human brain tumor cell lines to the clinically relevant methylating agents temozolomide and streptozotocin. Clin Cancer Res. 1996; 2:735-41. | Article I PubMed 
Julsing et al. Oncology Discovery 2014,

51. Bobola MS, Kolstoe DD, Blank A and Silber JR. Minimally cytotoxic doses of temozolomide produce radiosensitization in human glioblastoma cells regardless of MGMT expression. Mol Cancer Ther. 2010; 9:1208-18. | Article | PubMed Abstract | PubMed Full Text

52. Carlson BL, Grogan PT, Mladek AC, Schroeder MA, Kitange GJ, Decker PA, Giannini C, Wu W, Ballman KA, James CD and Sarkaria JN. Radiosensitizing effects of temozolomide observed in vivo only in a subset of 06-methylguanine-DNA methyltransferase methylated glioblastoma multiforme xenografts. Int J Radiat Oncol Biol Phys. 2009; 75:212-9. | Article | PubMed Abstract | PubMed Full Text

53. Esteller M, Garcia-Foncillas J, Andion E, Goodman SN, Hidalgo OF, Vanaclocha V, Baylin SB and Herman JG. Inactivation of the DNA-repair gene MGMT and the clinical response of gliomas to alkylating agents. N Engl J Med. 2000; 343:1350-4. | Article | PubMed

54. Pietanza MC, Kadota K, Huberman K, Sima CS, Fiore JJ, Sumner DK, Travis WD, Heguy A, Ginsberg MS, Holodny Al, Chan TA, Rizvi NA, Azzoli CG, Riely GJ, Kris MG and Krug LM. Phase II trial of temozolomide in patients with relapsed sensitive or refractory small cell lung cancer, with assessment of methylguanine-DNA methyltransferase as a potential biomarker. Clin Cancer Res. 2012; 18:1138-45. | Article | PubMed

55. Quiros S, Roos WP and Kaina B. Processing of O6-methylguanine into DNA double-strand breaks requires two rounds of replication whereas apoptosis is also induced in subsequent cell cycles. Cell Cycle. 2010; 9:168-78. | Article | PubMed

56. Kaina B, Margison GP and Christmann M. Targeting O(6)methylguanine-DNA methyltransferase with specific inhibitors as a strategy in cancer therapy. Cell Mol Life Sci. 2010; 67:3663-81. | Article I PubMed

57. Quinn JA, Jiang SX, Reardon DA, Desjardins A, Vredenburgh JJ, Rich $J \mathrm{~N}$, Gururangan S, Friedman AH, Bigner DD, Sampson JH, McLendon $\mathrm{RE}$, Herndon JE, 2nd, Walker A and Friedman HS. Phase II trial of temozolomide plus o6-benzylguanine in adults with recurrent, temozolomide-resistant malignant glioma. J Clin Oncol. 2009; 27:12627. | Article | PubMed Abstract | PubMed Full Text

58. Warren KE, Gururangan S, Geyer JR, McLendon RE, Poussaint TY, Wallace D, Balis FM, Berg SL, Packer RJ, Goldman S, Minturn JE, Pollack IF, Boyett JM and Kun LE. A phase II study of O6-benzylguanine and temozolomide in pediatric patients with recurrent or progressive high-grade gliomas and brainstem gliomas: a Pediatric Brain Tumor Consortium study. J Neurooncol. 2012; 106:643-9. | Article | PubMed Abstract | PubMed Full Text

59. Batts ED, Maisel C, Kane D, Liu L, Fu P, O'Brien T, Remick S, Bahlis N and Gerson SL. O6-benzylguanine and BCNU in multiple myeloma: a phase II trial. Cancer Chemother Pharmacol. 2007; 60:415-21. | Article I PubMed

60. Quinn JA. Phase II Trial of Carmustine Plus O6-Benzylguanine for Patients With Nitrosourea-Resistant Recurrent or Progressive Malignant Glioma. J Clin Oncol. 2002; 20:2277-2283.

61. Ryan CW, Dolan ME, Brockstein BB, McLendon R, Delaney SM, Samuels $\mathrm{BL}$, Agamah ES and Vokes EE. A phase II trial of O6-benzylguanine and carmustine in patients with advanced soft tissue sarcoma. Cancer Chemother Pharmacol. 2006; 58:634-9. | Article | PubMed

62. Gajewski TF, Sosman J, Gerson SL, Liu L, Dolan E, Lin S and Vokes EE. Phase II trial of the 06-alkylguanine DNA alkyltransferase inhibitor 06-benzylguanine and 1,3-bis(2-chloroethyl)-1-nitrosourea in advanced melanoma. Clin Cancer Res. 2005; 11:7861-5. | Article | PubMed

63. Shibata T, Glynn N, McMurry TB, McElhinney RS, Margison GP and Williams DM. Novel synthesis of O6-alkylguanine containing oligodeoxyribonucleotides as substrates for the human DNA repair protein, 06-methylguanine DNA methyltransferase (MGMT). Nucleic Acids Res. 2006; 34:1884-91. | Article | PubMed Abstract | PubMed Full Text

64. Ranson M, Hersey P, Thompson D, Beith J, McArthur GA, Haydon A, Davis ID, Kefford RF, Mortimer P, Harris PA, Baka S, Seebaran A, Sabharwal A, Watson AJ, Margison GP and Middleton MR. Randomized trial of the combination of lomeguatrib and temozolomide compared with temozolomide alone in chemotherapy naive patients with metastatic cutaneous melanoma. J Clin Oncol. 2007; 25:2540-5. I Article | PubMed

65. Khan OA, Ranson M, Michael M, Olver I, Levitt NC, Mortimer P, Watson AJ, Margison GP, Midgley R and Middleton MR. A phase II trial of lomeguatrib and temozolomide in metastatic colorectal cancer. $\mathrm{Br} J$ Cancer. 2008; 98:1614-8. | Article | PubMed Abstract | PubMed Full $\underline{\text { Text }}$

66. Watson AJ, Middleton MR, McGown G, Thorncroft M, Ranson M, Hersey P, McArthur G, Davis ID, Thomson D, Beith J, Haydon A, Kefford $R$, Lorigan $P$, Mortimer $P$, Sabharwal A, Hayward $O$ and Margison GP. O(6)-methylguanine-DNA methyltransferase depletion and DNA damage in patients with melanoma treated with temozolomide alone or with lomeguatrib. Br J Cancer. 2009; 100:1250-6. | Article | PubMed Abstract | PubMed Full Text

67. Scully R, Chen J, Plug A, Xiao Y, Weaver D, Feunteun J, Ashley T and Livingston DM. Association of BRCA1 with Rad51 in mitotic and meiotic cells. Cell. 1997; 88:265-75. | Article | PubMed

68. Yun MH and Hiom K. CtIP-BRCA1 modulates the choice of DNA doublestrand-break repair pathway throughout the cell cycle. Nature. 2009; 459:460-3. | Article | PubMed Abstract | PubMed Full Text

69. Martin RW, Orelli BJ, Yamazoe M, Minn AJ, Takeda S and Bishop DK. RAD51 up-regulation bypasses BRCA1 function and is a common feature of BRCA1-deficient breast tumors. Cancer Res. 2007; 67:965865. | Article | PubMed

70. Zhuang J, Zhang J, Willers $\mathrm{H}$, Wang $\mathrm{H}$, Chung JH, van Gent DC, Hallahan DE, Powell SN and Xia F. Checkpoint kinase 2-mediated phosphorylation of BRCA1 regulates the fidelity of nonhomologous end-joining. Cancer Res. 2006; 66:1401-8. | Article | PubMed

71. Wang HC, Chou WC, Shieh SY and Shen CY. Ataxia telangiectasia mutated and checkpoint kinase 2 regulate BRCA1 to promote the fidelity of DNA end-joining. Cancer Res. 2006; 66:1391-400. | Article | PubMed

72. Zhang J, Willers H, Feng Z, Ghosh JC, Kim S, Weaver DT, Chung JH, Powell SN and Xia F. Chk2 phosphorylation of BRCA1 regulates DNA double-strand break repair. Mol Cell Biol. 2004; 24:708-18. | Article | PubMed Abstract | PubMed Full Text

73. Yang D, Khan S, Sun Y, Hess K, Shmulevich I, Sood AK and Zhang W. Association of BRCA1 and BRCA2 mutations with survival, chemotherapy sensitivity, and gene mutator phenotype in patients with ovarian cancer. JAMA. 2011; 306:1557-65. | Article | PubMed Abstract | PubMed Full Text

74. Veeck J, Ropero S, Setien F, Gonzalez-Suarez E, Osorio A, Benitez J, Herman JG and Esteller M. BRCA1 CpG island hypermethylation predicts sensitivity to poly(adenosine diphosphate)-ribose polymerase inhibitors. J Clin Oncol. 2010; 28:e563-4; author reply e565-6. | Article | PubMed

75. Xu Y, Diao L, Chen Y, Liu Y, Wang C, Ouyang T, Li J, Wang T, Fan Z, Fan T, Lin B, Deng D, Narod SA and Xie Y. Promoter methylation of BRCA1 in triple-negative breast cancer predicts sensitivity to adjuvant chemotherapy. Ann Oncol. 2013; 24:1498-505. | Article | PubMed

76. Ignatov T, Eggemann H, Costa SD, Roessner A, Kalinski T and Ignatov A. BRCA1 promoter methylation is a marker of better response to platinum-taxane-based therapy in sporadic epithelial ovarian cancer. $J$ Cancer Res Clin Oncol. 2014; 140:1457-63. | Article | PubMed

77. Stefansson OA, Villanueva A, Vidal A, Marti L and Esteller M. BRCA1 epigenetic inactivation predicts sensitivity to platinum-based chemotherapy in breast and ovarian cancer. Epigenetics. 2012; 7:1225-9. | Article | PubMed Abstract | PubMed Full Text

78. Watanabe Y, Maeda I, Oikawa R, Wu W, Tsuchiya K, Miyoshi Y, Itoh F, Tsugawa $\mathrm{K}$ and Ohta T. Aberrant DNA methylation status of DNA repair genes in breast cancer treated with neoadjuvant chemotherapy. Genes Cells. 2013; 18:1120-30. | Article | PubMed

79. Toyota M, Ahuja N, Ohe-Toyota M, Herman JG, Baylin SB and Issa JP. CpG island methylator phenotype in colorectal cancer. Proc Natl Acad Sci U S A. 1999; 96:8681-6. | Article | PubMed Abstract | PubMed Full Text 
Julsing et al. Oncology Discovery 2014,

http://www.hoajonline.com/journals/pdf/2052-6199-2-3.pdf

doi: $10.7243 / 2052-6199-2-3$

80. Carethers JM, Chauhan DP, Fink D, Nebel S, Bresalier RS, Howell SB and Boland CR. Mismatch repair proficiency and in vitro response to 5-fluorouracil. Gastroenterology. 1999; 117:123-31. | Article | PubMed

81. Barvaux VA, Ranson M, Brown R, McElhinney RS, McMurry TB and Margison GP. Dual repair modulation reverses Temozolomide resistance in vitro. Mol Cancer Ther. 2004; 3:123-7. I Article I PubMed

82. Watanabe $\mathrm{Y}$, Ueda $\mathrm{H}$, Etoh $\mathrm{T}$, Koike E, Fujinami N, Mitsuhashi A and Hoshiai $\mathrm{H}$. A change in promoter methylation of hMLH1 is a cause of acquired resistance to platinum-based chemotherapy in epithelial ovarian cancer. Anticancer Res. 2007; 27:1449-52. I Article I PubMed

83. Strathdee G, MacKean MJ, Illand M and Brown R. A role for methylation of the hMLH1 promoter in loss of hMLH1 expression and drug resistance in ovarian cancer. Oncogene. 1999; 18:2335-41. | Article I PubMed

84. Li Y, Yang Y, Lu Y, Herman JG, Brock MV, Zhao P and Guo M. Predictive value of CHFR and MLH1 methylation in human gastric cancer. Gastric Cancer. 2014. | Article | PubMed

85. Fink $D$, Aebi $S$ and Howell SB. The role of DNA mismatch repair in drug resistance. Clin Cancer Res. 1998; 4:1-6. I Article I PubMed

86. Fenaux P, Mufti GJ, Hellstrom-Lindberg E, Santini V, Finelli C, Giagounidis A, Schoch R, Gattermann N, Sanz G, List A, Gore SD, Seymour JF, Bennett JM, Byrd J, Backstrom J, Zimmerman L, McKenzie $D$, Beach C and Silverman LR. Efficacy of azacitidine compared with that of conventional care regimens in the treatment of higher-risk myelodysplastic syndromes: a randomised, open-label, phase III study. Lancet Oncol. 2009; 10:223-32. | Article | PubMed Abstract | PubMed Full Text

87. Arnold CN, Goel A and Boland CR. Role of hMLH1 promoter hypermethylation in drug resistance to 5 -fluorouracil in colorectal cancer cell lines. Int J Cancer. 2003; 106:66-73. | Article I PubMed

88. Plumb JA, Strathdee G, Sludden J, Kaye SB and Brown R. Reversal of drug resistance in human tumor xenografts by 2'-deoxy-5-azacytidineinduced demethylation of the hMLH1 gene promoter. Cancer Res. 2000; 60:6039-44. | Article | PubMed

89. Matei D, Fang F, Shen C, Schilder J, Arnold A, Zeng Y, Berry WA, Huang $T$ and Nephew KP. Epigenetic resensitization to platinum in ovarian cancer. Cancer Res. 2012; 72:2197-205. | Article | PubMed Abstract | PubMed Full Text

90. Hill BT, Scanlon KJ, Hansson J, Harstrick A, Pera M, Fichtinger-Schepman AM and Shellard SA. Deficient repair of cisplatin-DNA adducts identified in human testicular teratoma cell lines established from tumours from untreated patients. Eur J Cancer. 1994; 30A:832-7. | Article I PubMed

91. De Dosso S, Zanellato E, Nucifora M, Boldorini R, Sonzogni A, Biffi R, Fazio N, Bucci E, Beretta O, Crippa S, Saletti P and Frattini M. ERCC1 predicts outcome in patients with gastric cancer treated with adjuvant cisplatin-based chemotherapy. Cancer Chemother Pharmacol. 2013; 72:159-65. | Article | PubMed

92. Britten RA, Liu D, Tessier A, Hutchison MJ and Murray D. ERCC1 expression as a molecular marker of cisplatin resistance in human cervical tumor cells. Int J Cancer. 2000; 89:453-7. | Article I PubMed

93. Chen HY, Shao CJ, Chen FR, Kwan AL and Chen ZP. Role of ERCC1 promoter hypermethylation in drug resistance to cisplatin in human gliomas. Int J Cancer. 2010; 126:1944-54. | Article | PubMed

94. Liu ZG, Chen HY, Cheng JJ, Chen ZP, Li XN and Xia YF. Relationship between methylation status of ERCC1 promoter and radiosensitivity in glioma cell lines. Cell Biol Int. 2009; 33:1111-7. | Article I PubMed

95. Lalezari S, Chou AP, Tran A, Solis OE, Khanlou N, Chen W, Li S, Carrillo JA, Chowdhury R, Selfridge J, Sanchez DE, Wilson RW, Zurayk M, Lalezari J, Lou JJ, Ormiston L, Ancheta K, Hanna R, Miller P, Piccioni D, Ellingson BM, Buchanan C, Mischel PS, Nghiemphu PL, Green R, Wang HJ, Pope WB, Liau LM, Elashoff RM, Cloughesy TF, Yong WH and Lai A. Combined analysis of 06-methylguanine-DNA methyltransferase protein expression and promoter methylation provides optimized prognostication of glioblastoma outcome. Neuro Oncol. 2013; 15:37081. | Article | PubMed Abstract | PubMed Full Text

96. Skiriute D, Vaitkiene P, Asmoniene V, Steponaitis G, Deltuva VP and
Tamasauskas A. Promoter methylation of AREG, HOXA11, hMLH1, NDRG2, NPTX2 and Tes genes in glioblastoma. J Neurooncol. 2013; 113:441-9. | Article | PubMed

97. Melguizo C, Prados J, Gonzalez B, Ortiz R, Concha A, Alvarez PJ, Madeddu R, Perazzoli G, Oliver JA, Lopez R, Rodriguez-Serrano F and Aranega A. MGMT promoter methylation status and MGMT and CD133 immunohistochemical expression as prognostic markers in glioblastoma patients treated with temozolomide plus radiotherapy. J Transl Med. 2012; 10:250. | Article | PubMed Abstract | PubMed Full $\underline{\text { Text }}$

98. Peng B, Hurt EM, Hodge DR, Thomas SB and Farrar WL. DNA hypermethylation and partial gene silencing of human thymine- DNA glycosylase in multiple myeloma cell lines. Epigenetics. 2006; 1:13845. I Article | PubMed

99. Howard JH, Frolov A, Tzeng CW, Stewart A, Midzak A, Majmundar A, Godwin A, Heslin M, Bellacosa A and Arnoletti JP. Epigenetic downregulation of the DNA repair gene MED1/MBD4 in colorectal and ovarian cancer. Cancer Biol Ther. 2009; 8:94-100. | Article | PubMed Abstract | PubMed Full Text

100. Guan H, Ji M, Hou P, Liu Z, Wang C, Shan Z, Teng W and Xing M. Hypermethylation of the DNA mismatch repair gene hMLH1 and its association with lymph node metastasis and T1799A BRAF mutation in patients with papillary thyroid cancer. Cancer. 2008; 113:247-55. | Article I PubMed

101. Yang J, Xu Z, Li J, Zhang R, Zhang G, Ji H, Song B and Chen Z. XPC epigenetic silence coupled with $\mathrm{p} 53$ alteration has a significant impact on bladder cancer outcome. J Urol. 2010; 184:336-43. | Article | PubMed

102. Wu YH, Tsai Chang JH, Cheng YW, Wu TC, Chen CY and Lee $\mathrm{H}$. Xeroderma pigmentosum group $\mathrm{C}$ gene expression is predominantly regulated by promoter hypermethylation and contributes to p53 mutation in lung cancers. Oncogene. 2007; 26:4761-73. | Article | PubMed

103. Peng B, Hodge DR, Thomas SB, Cherry JM, Munroe DJ, Pompeia C, Xiao W and Farrar WL. Epigenetic silencing of the human nucleotide excision repair gene, hHR23B, in interleukin-6-responsive multiple myeloma KAS-6/1 cells. J Biol Chem. 2005; 280:4182-7. | Article | PubMed

104. Kane MF, Loda M, Gaida GM, Lipman J, Mishra R, Goldman H, Jessup JM and Kolodner R. Methylation of the hMLH1 promoter correlates with lack of expression of hMLH1 in sporadic colon tumors and mismatch repair-defective human tumor cell lines. Cancer Res. 1997; 57:808-11. | Article | PubMed

105. Cunningham JM, Christensen ER, Tester DJ, Kim CY, Roche PC, Burgart LJ and Thibodeau SN. Hypermethylation of the hMLH1 promoter in colon cancer with microsatellite instability. Cancer Res. 1998; 58:3455-60. | Article | PubMed

106. Esteller M, Levine R, Baylin SB, Ellenson LH and Herman JG. MLH1 promoter hypermethylation is associated with the microsatellite instability phenotype in sporadic endometrial carcinomas. Oncogene. 1998; 17:2413-7. I Article I PubMed

107. Fleisher AS, Esteller M, Wang S, Tamura G, Suzuki H, Yin J, Zou TT, Abraham JM, Kong D, Smolinski KN, Shi YQ, Rhyu MG, Powell SM, James SP, Wilson KT, Herman JG and Meltzer SJ. Hypermethylation of the hMLH1 gene promoter in human gastric cancers with microsatellite instability. Cancer Res. 1999; 59:1090-5. | Article | PubMed

108. Sakata K, Tamura G, Endoh Y, Ohmura K, Ogata S and Motoyama T. Hypermethylation of the hMLH1 gene promoter in solitary and multiple gastric cancers with microsatellite instability. $\mathrm{Br} J$ Cancer. 2002; 86:564-7. | Article | PubMed Abstract | PubMed Full Text

109. Chen HZ, Ye DF, Xie X, Hu M and Lu WG. [Hypermethylation of hMLH1 and microsatellite instability in ovarian mucinous tumors]. Zhongguo Yi Xue Ke Xue Yuan Xue Bao. 2003; 25:457-61. I PubMed

110. Zhang H, Zhang S, Cui J, Zhang A, Shen L and Yu H. Expression and promoter methylation status of mismatch repair gene hMLH1 and hMSH2 in epithelial ovarian cancer. Aust N Z J Obstet Gynaecol. 2008; 48:505-9. | Article | PubMed 
Julsing et al. Oncology Discovery 2014,

111. Seedhouse $\mathrm{CH}$, Das-Gupta EP and Russell NH. Methylation of the hMLH1 promoter and its association with microsatellite instability in acute myeloid leukemia. Leukemia. 2003; 17:83-8. I Article I PubMed

112. Wang YC, Lu YP, Tseng RC, Lin RK, Chang JW, Chen JT, Shih CM and Chen $\mathrm{CY}$. Inactivation of hMLH1 and hMSH2 by promoter methylation in primary non-small cell lung tumors and matched sputum samples. J Clin Invest. 2003; 111:887-95. | Article | PubMed Abstract | PubMed Full Text

113. Liu K, Huang H, Mukunyadzi P, Suen JY, Hanna E and Fan CY. Promoter hypermethylation: an important epigenetic mechanism for hMLH1 gene inactivation in head and neck squamous cell carcinoma. Otolaryngol Head Neck Surg. 2002; 126:548-53. I Article I PubMed

114. Zuo C, Zhang H, Spencer HJ, Vural E, Suen JY, Schichman SA, Smoller BR, Kokoska MS and Fan CY. Increased microsatellite instability and epigenetic inactivation of the hMLH1 gene in head and neck squamous cell carcinoma. Otolaryngol Head Neck Surg. 2009; 141:48490. | Article | PubMed

115. Czerninski R, Krichevsky S, Ashhab Y, Gazit D, Patel V and Ben-Yehuda D. Promoter hypermethylation of mismatch repair genes, hMLH1 and hMSH2 in oral squamous cell carcinoma. Oral Dis. 2009; 15:206-13. | Article I PubMed

116. Herfarth KK, Brent TP, Danam RP, Remack JS, Kodner IJ, Wells SA, Jr. and Goodfellow PJ. A specific CpG methylation pattern of the MGMT promoter region associated with reduced MGMT expression in primary colorectal cancers. Mol Carcinog. 1999; 24:90-8. | Article | PubMed

117. Oue N, Shigeishi H, Kuniyasu H, Yokozaki H, Kuraoka K, Ito R and Yasui W. Promoter hypermethylation of MGMT is associated with protein loss in gastric carcinoma. Int J Cancer. 2001; 93:805-9. | Article | PubMed

118. Wolf P, Hu YC, Doffek K, Sidransky D and Ahrendt SA. O(6)Methylguanine-DNA methyltransferase promoter hypermethylation shifts the $\mathbf{p} 53$ mutational spectrum in non-small cell lung cancer. Cancer Res. 2001; 61:8113-7. | Article | PubMed

119. Goldenberg D, Harden S, Masayesva BG, Ha P, Benoit N, Westra WH, Koch WM, Sidransky D and Califano JA. Intraoperative molecular margin analysis in head and neck cancer. Arch Otolaryngol Head Neck Surg. 2004; 130:39-44. I Article I PubMed

120. Banzai C, Nishino K, Quan J, Yoshihara K, Sekine M, Yahata T and Tanaka K. Promoter methylation of DAPK1, FHIT, MGMT, and CDKN2A genes in cervical carcinoma. Int J Clin Oncol. 2014; 19:127-32. | Article | PubMed

121. Lee MN, Tseng RC, Hsu HS, Chen JY, Tzao C, Ho WL and Wang YC. Epigenetic inactivation of the chromosomal stability control genes BRCA1, BRCA2, and XRCC5 in non-small cell lung cancer. Clin Cancer Res. 2007; 13:832-8. | Article | PubMed

122. Wang YQ, Yan Q, Zhang JR, Li SD, Yang YX and Wan XP. Epigenetic inactivation of BRCA1 through promoter hypermethylation in ovarian cancer progression. J Obstet Gynaecol Res. 2013; 39:549-54. | Article | PubMed

123. Xing D, Scangas G, Nitta M, He L, Xu X, loffe YJ, Aspuria PJ, Hedvat CY, Anderson ML, Oliva E, Karlan BY, Mohapatra G and Orsulic S. A role for BRCA1 in uterine leiomyosarcoma. Cancer Res. 2009; 69:8231-5. I Article | PubMed Abstract | PubMed Full Text

124. Bernal C, Vargas M, Ossandon F, Santibanez E, Urrutia J, Luengo V, Zavala LF, Backhouse C, Palma M, Argandona J, Aguayo F and Corvalan A. DNA methylation profile in diffuse type gastric cancer: evidence for hypermethylation of the BRCA1 promoter region in early-onset gastric carcinogenesis. Biol Res. 2008; 41:303-15. | Article | PubMed

125. Yu J, Zhu T, Wang Z, Zhang H, Qian Z, Xu H, Gao B, Wang W, Gu L, Meng J, Wang J, Feng $X$, Li Y, Yao $X$ and Zhu J. A novel set of DNA methylation markers in urine sediments for sensitive/specific detection of bladder cancer. Clin Cancer Res. 2007; 13:7296-304. I Article I PubMed

126. Raguz S, Adams C, Masrour N, Rasul S, Papoutsoglou P, Hu Y, Cazzanelli G, Zhou Y, Patel N, Coombes C and Yague E. Loss of O(6)methylguanine-DNA methyltransferase confers collateral sensitivity to carmustine in topoisomerase II-mediated doxorubicin resistant triple negative breast cancer cells. Biochem Pharmacol. 2013; 85:186-96. | Article I PubMed

127. Amatu A, Sartore-Bianchi A, Moutinho C, Belotti A, Bencardino K, Chirico G, Cassingena A, Rusconi F, Esposito A, Nichelatti M, Esteller M and Siena S. Promoter CpG island hypermethylation of the DNA repair enzyme MGMT predicts clinical response to dacarbazine in a phase II study for metastatic colorectal cancer. Clin Cancer Res. 2013; 19:226572. | Article | PubMed

128. Zeller C, Dai W, Steele NL, Siddiq A, Walley AJ, Wilhelm-Benartzi CS, Rizzo S, van der Zee A, Plumb JA and Brown R. Candidate DNA methylation drivers of acquired cisplatin resistance in ovarian cancer identified by methylome and expression profiling. Oncogene. 2012; 31:4567-76. | Article | PubMed

129. Hegi ME, Liu L, Herman JG, Stupp R, Wick W, Weller M, Mehta MP and Gilbert MR. Correlation of 06-methylguanine methyltransferase (MGMT) promoter methylation with clinical outcomes in glioblastoma and clinical strategies to modulate MGMT activity. J Clin Oncol. 2008; 26:4189-99. | Article | PubMed

Citation:

Julsing JR and Peters GJ. Methylation of DNA repair genes and the efficacy of DNA targeted anticancer treatment. Oncol Discov. 2014; 2:3. http://dx.doi.org/10.7243/2052-6199-2-3 